\title{
Rancang Bangun Sistem Informasi Layanan Analisis Sampel Berbasis Android Pada Laboratorium Fisika Unnes
}

\author{
Rodhotul Muttaqin ${ }^{1}$, Natalia Erna S. ${ }^{2}$, David Mubarok ${ }^{3}$ \\ ${ }^{1}$ PLP Ahli Muda, Laboratorium Fisika, Universitas Negeri Semarang, Semarang, 50229 \\ muttaqinfisika@mail.unnes .ac.id \\ ${ }^{2}$ PLP Ahli Muda, Laboratorium Fisika, Universitas Negeri Semarang, Semarang, 50229 \\ nataliaerna@mail.unnes.ac.id \\ ${ }^{3}$ Teknisi Laboratorium Matematika, Universitas Negeri Semarang, Semarang, 50229 \\ davidmubarok@mail.unnes .ac.id
}

\begin{abstract}
ABSTRAK
Laboratorium Fisika telah memiliki layanan analisis sampel untuk beberapa jenis pengujian seperti analisis struktur kristal, analisis morfologi permukaan sampel, analisis gugus fungsi sampel dan lain-lain. Proses layanan pengujian sampel selama ini masih menggunakan berkasberkas fisik berupa form kertas yang harus ditulis untuk mengajukan pengujian sampel. Berkasberkas fisik ini rentan hilang atau tercecer sehingga dipandang kurang efektif dan tidak sejalan dengan kebijakan Unnes yang mengedepankan konservasi dan meminimalkan penggunaan kertas (paperless). Sistem informasi layanan pengujian sampel online memberikan kemudahan dalam mengakses informasi secara realtime mengenai status proses pengerjaan sampel melalui aplikasi android yang dikembangkan. Pada penelitian ini dilakukan kegiatan rancang bangun sistem informasi layanan analisis sampel berbasis android pada Laboratorium Fisika Unnes. Sistem informasi berbasis website dikembangkan dengan framework Code Igniter versi 3 dan MySQL sebagai sistem basis data (database). Aplikasi android dikembangkan dengan menggunakan Software Opensource berupa Android studio dari Google. Metode yang digunakan adalah metode waterfall. Pengujian yang dilakukan pada sistem adalah dengan menggunakan alpha test dan beta test. Hasil pengujian menunjukkan sistem dapat diimplementasikan dengan baik sehingga sistem dapat berjalan sesuai kebutuhan.
\end{abstract}

Kata Kunci: Sistem Informasi, Layanan pengujian sampel, Android, Laboratoorium Fisika

\section{PENDAHULUAN}

Laboratorium adalah unit penunjang akademik pada lembaga pendidikan, berupa ruangan tertutup atau terbuka, bersifat permanen atau bergerak, dikelola secara sistematis untuk kegiatan pengujian, kalibrasi, dan/atau produksi dalam skala terbatas, dengan menggunakan peralatan dan bahan berdasarkan metode keilmuan tertentu, dalam rangka pelaksanaan pendidikan, penelitian, dan/atau pengabdian kepada masyarakat. Laboratorium Fisika Unnes merupakan laboratorium yang melakukan dua fungsi utama yaitu melayani penelitian dan pendidikan. Laboratorium Fisika juga telah didukung dengan peralatan yang dapat digunakan untuk analisis sampel seperti
XRD (X-Ray Diffractometer), SEM (Scanning Electron Microscopy), FTIR (Fourier Transform Infra Red Spectrophotometer) dan lain-lain. Dalam perkembangannya Laboratorium Fisika telah membuka layanan pengujian atau analisis sampel yang dapat digunakan oleh mahasiswa, dosen maupun peneliti dari kalangan masyarakat umum.

Proses pendataan dan mekanisme pengujian sampel yang selama ini berjalan di Laboratorium Fisika adalah dengan menggunakan prosedur yang telah ditetapkan oleh Kepala Laboratorium. Proses ini masih menggunakan borang (form) isian berbentuk fisik untuk memasukkan identitas pelanggan, identitas 
sampel dan jenis pengujian yang diinginkan. Proses selanjutnya adalah pengkodean sampel yang diterima untuk kemudian dilakukan pengkajian ulang proses pengujian oleh manajer teknis. Kemudian masuk pada antrian sampel yang telah ada untuk dikerjakan oleh analis dan kemudian dilaporkan kepada manajer teknis. Tahapan akhir dari proses ini adalah pembuatan surat keterangan hasil pengujian yang diserahkan kepada pelanggan setelah pelanggan membayar biaya pengujian yang dikenakan. Tahapan demi tahapan proses tersebut tidak dapat diakses oleh pelanggan secara langsung karena belum adanya sistem yang mengaturnya.

Seiring dengan berkembangnya teknologi informasi dan komunikasi, pemanfaatan teknologi komputer berbasis online sangat tepat untuk membantu pengelolaan laboratorium. Teknologi informasi berfungsi mempercepat proses, mengurangi tingkat kesalahan, mengolah data, dan akhirnya menghasilkan informasi yang akan mendukung pengambilan keputusan. Teknologi informasi dapat dimanfaatkan dalam semua bidang pekerjaan termasuk pada laboratorium teknis (Trisnato \& Lala, 2016).

Untuk meningkatkan layanan analisis atau pengujian sampel yang dilakukan Laboratorium Fisika diperlukan sebuah sistem informasi online yang dapat diakses oleh pelanggan baik melalui komputer dekstop maupun melalui gawai berbasis android. Sistem informasi layanan analisis sampel yang dikembangkan hendaknya memberikan informasi administratif mulai dari proses pendaftaran pelanggan, proses pendaftaran pengujian, serta permintaan khusus selama proses pengujian berlangsung. Output yang dihasilkan adalah berupa tanda terima pengujian, kwitansi pembayaran, status pengujian, laporan status pembayaran, laporan bulanan serta daftar pelanggan.

Pada penelitian ini akan dilakukan kegiatan rancang bangun sistem informasi layanan analisis sampel berbasis android pada Laboratorium Fisika Unnes. Sistem informasi berbasis website dikembangkan dengan framework Code Igniter versi 3 dan MySQL sebagai sistem basis data (database). Aplikasi android dikembangkan dengan menggunakan Software Opensource berupa Android studio dari Google.

Tujuan dari penelitian ini antara lain adalah merancang bangun sebuah sistem informasi layanan analisis sampel berbasis Android pada Laboratorium Fisika dan membuat aplikasi android yang digunakan untuk mengakses sistem informasi layanan analisis sampel Laboratorium Fisika

\section{Pengertian Sistem Informasi}

Sistem (system) dapat didefinisikan dengan pendekatan prosedur dan dengan pendekatan komponen. Dengan pendekatan prosedur, sistem dapat didefinisikan sebagai kumpulan dari prosedur-prosedur yang mempunyai tujuan tertentu. Dengan pendekatan komponen sistem dapat didefinisikan sebagai kumpulan dari komponen yang saling berhubungan satu dengan yang lainnya membentuk satu kesatuan untuk mencapai tujuan tertentu (Jogiyanto, 2005).

Informasi adalah data yang diolah menjadi bentuk yang berguna bagi pemakainya. Untuk dapat berguna, maka informasi harus didukung oleh tiga pilar sebagai berikut : tepat sasaran (relevan), tepat waktu, dan tepat nilainya (akurat). Informasi yang tidak didukung oleh ketiga pilar ini dikatakan sebagai informasi yang tidak berguna (Jogiyanto, 2005).

\section{Bahasa Pemrograman PHP}

PHP adalah bahasa pemrograman script yang paling banyak dipakai saat ini. PHP banyak dipakai untuk memrogram situs web dinamis, walaupun tidak tertutup kemungkinan digunakan untuk pemakaian lain (Ramadhani, Anis, \& Masruro, 2013). PHP adalah bahasa server-side scripting yang menyatu dengan HTML untuk membuat halaman web yang dinamis . Server-side scripting adalah sintaks dan perintah-perintah yang digunakan atau 
dijalankan di server tetapi disertakan pada dokumen HTML. Pembuatan web ini merupakan kombinasi antara PHP sebagai bahasa pemrograman dan HTML sebagai pembangun halaman web.

\section{MySQL}

MySQL adalah sebuah server database open source yang terkenal yang digunakan berbagai aplikasi terutama untuk server atau membuat webservice. MySQL berfungsi sebagai Structured Query Language (SQL) yang dimiliki sendiri dan sudah diperluas oleh MySQL yang umumnya digunakan bersamaan dengan PHP untuk membuat aplikasi server yang dinamis dan powerfull. Kehandalan suatu sistem basisdata (DBMS) dapat diketahui dari cara kerja dalam melakukan proses perintahperintah SQL yang dibuat oleh pengguna maupun program-program aplikasi yang memanfaatkannya. Sebagai pengoperasi basis data, MySQL mendukung operasi basisdata transaksional maupun operasi basisdata non-transaksional ( Irsan, 2015).

\section{Framework}

Framework merupakan kerangka kerja yang memudahkan programmer untuk membuat sebuah aplikasi sehingga programmer akan lebih mudah melakukan perubahan (customize) terhadap aplikasinya dan dapat memakainya kembali untuk aplikasi lain yang sejenis. Berdasakan penjelasan di atas framework merupakan kerangka kerja yang memudahkan programmer untuk membuat aplikasi dengan library fungsi-fungsi yang sudah diorganisasikan untuk dapat membuat suatu program dengan cepat (Suharsana, Wirarama, Wirawan, Luh, \& Kartika, 2016).

\section{Code Igniter}

Code Igniter (CI) adalah sebuah framework yang digunakan untuk membuat sebuah aplikasi berbasis web yang disusun dengan menggunakan bahasa PHP. Di dalam CI terdapat beberapa macam kelas (class) yang berbentuk library dan helper. Keduanya berfungsi untuk membantu pemrogram (programmer) dalam mengembangkan aplikasinya (Riyanto, 2011). Code Igniter (CI) adalah framework pengembangan aplikasi dengan menggunakan PHP, suatu kerangka untuk bekerja atau membuat program dengan menggunakan PHP yang lebih sistematis. MVC adalah konsep dasar yang harus diketahui sebelum mengenal Codeigniter. MVC adalah singkatan dari Model View Controller. MVC sebenarnya adalah sebuah teknik pemrograman yang memisahkan alur bisnis, penyimpanan data dan antarmuka aplikasi atau secara sederhana adalah memisahkan antara desain, data dan proses (Suharsana et al., 2016).

\section{Android Studio}

Android Studio adalah Integrated Development Environtment (IDE) resmi untuk pengembangan aplikasi android dan bersifat opensource atau gratis (Juansyah, 2015). Hal itu disampaikan pada tanggal 16 Mei 2013 di Google I / O konferensi dengan Product Manager Google, Katherine Chou - Android Studio tersedia secara bebas di bawah Lisensi Apache 2.0. Android studio sendiri dikembangkan berdasarkan IntelliJ IDEA yang mirip dengan Eclipse disertai dengan ADT plugin (Android Development Tools).

\section{METODE PENELITIAN Model Pengembangan}

Prosedur pengembangan yang digunakan pada sistem informasi layanan analisis sampel berbasis android ini adalah menggunakan prosedur pengembangan model Waterfall. Model ini melakukan pendekatan secara sistematis dan urut mulai dari level kebutuhan sistem lalu menuju ke tahap analisis, desain dan coding, Pengujian sistem, dan implementasi dan pemeliharaan. Disebut dengan waterfall karena tahap demi tahap yang dilalui harus menunggu selesainya tahap sebelumnya 
dan berjalan berurutan (Musleh Al Hayubi, Zainal Arifin, 2016). Sebagai contoh tahap desain harus menunggu selesainya tahap sebelumnya yaitu tahap requirement. Secara umum tahapan pada model waterfall dapat dilihat pada gambar 1 berikut:

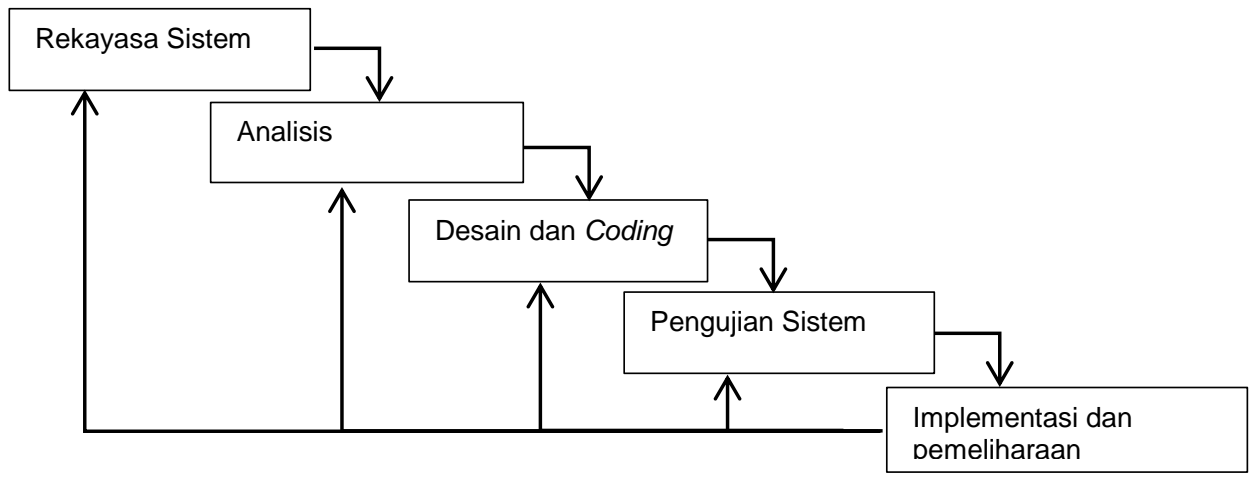

Gambar 1. Siklus Pengembangan dengan metode Waterfall

Gambar 1 merupakan tahapan yang digunakan dalam penelitian ini. Penjelasan tiap tahapan penelitian adalah sebagai berikut:

\section{a. Rekayasa Sistem (Information Engineering)}

Pada tahap ini peneliti melakukan observasi dan pengumpulan data awal terkait proses pengujian sampel yang dilakukan di Laboratorium Fisika. Data yang diperlukan antara lain Standard Operational Prosedur (SOP) penerimaan sampel, bentuk isian form penerimaan sampel, serta prosedur pembayaran di Laboratorium Fisika.

\section{b. Analisis}

Analisis sistem dilakukan dengan wawancara, observasi dan studi literatur. Dengan menganalisis hasil tahapan ini selanjutnya dapat ditentukan kebutuhan sistem informasi layanan analsis sampel yang baru berbasis android dengan melakukan sedikit perubahan pada SOP yang telah ada.

c. Desain dan Penulisan Kode Program (Coding)

Setelah melakukan analisa kebutuhan selanjutnya peneliti membuat rancangan

Dari hasil analisis pembacaan standard opeasional prosedur (SOP) penerimaan sampel Laboratorium Fisika serta hasil wawancara dengan petugas dan atau desain sistem informasi layanan pengujian sampel berbasis android yang hendak dibuat. Rancangan yang dibuat berupa flowchart, DFD, dan Bagan berjenjang. Hasil perancangan yang dibuat kemudian diimplementasikan dalam program aplikasi yang didalamnya memuat pengkonversian dari bahasa manusia ke bahasa mesin sehingga tercipta sebuah sistem baru.

\section{d. Pengujian Sistem}

Setelah sistem informasi layanan analisis sampel selesai dibuat, tahap berikutnya adalah mengujicoba sistem tersebut. Tujuan dari tahapan ini adalah untuk memberikan umpan balik dari pengguna apabila terdapat kesalahan- kesalahan pada sistem untuk kemudian dapat diperbaiki.

e. Implementasi dan Pemeliharaan

Setelah sistem lolos pengujian selanjutnya implementasi sistem disosialisasikan kepada pengguna. Agar sistem selalu dapat digunakan dengan baik maka perlu dilakukan perawatan secara berkala untuk mengatasi berbagai permasalahan yang mungkin muncul.

\section{Perancangan Sistem}

pelanggan, dapat disimpulkan jika sistem informasi analisis sampel terbagi menjadi dua sisi, yaitu pelanggan (user) dan administrator layanan (Operator). Pelanggan 
(user) mengunduh aplikasi SIMPLE (sistem informasi layanan analisis sampel) di Google Playstore dengan gawai (gadget) berbasis android. Kemudian sisi operator 四 berbasis web untuk memproses data sesuai dengan SOP yang berlaku di Laboratorium Fisika. Gambar 2 menunjukkan aplikasi SIMPLE pada Google Playstore

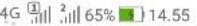

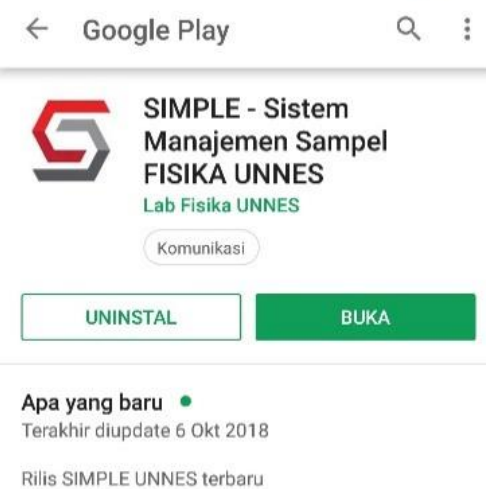

Gambar 2. Aplikasi SIMPLE pada Google Playstore

Prosedur layanan pengujian sampel yang dimiliki laboratorium fisika saat ini masih menggunakan sistem pengisian Formulir Penerimaan Sampel secara langsung dengan menggunakan kertas. Form penerimaan sampel (FPS) berisi identitas pelanggan, identitas sampel dan jenis pengujian yang diminta beserta permintaan khusus yang diinginkan oleh pelanggan. Proses berikutnya adalah petugas penerima sampel menyerahkan FPS dan sampel kepada analis untuk dianalisis. Setelah sampel berhasil dianalisis kemudian manajer teknis memeriksa hasil untuk diverifikasi. Proses berikutnya administrator layanan kemudian menghubungi pelanggan untuk melakukan pembayaran dan pengambilan data.

Standard Operasional Prosedur tersebut perlu disesuaikan untuk sistem informasi layanan pengujian sampel yang dibuat. Proses penyesuaian tersebut dilakukan untuk dapat lebih memudahkan pelanggan dalam melacak status analisis sampel.

\section{Pengembangan Aplikasi Android}

Pengembangan aplikasi android memiliki tujuan utama yaitu melakukan pendataan identitas user serta pendaftaran sampel. Gambar 3 menunjukkan alur kerja proses pada user.

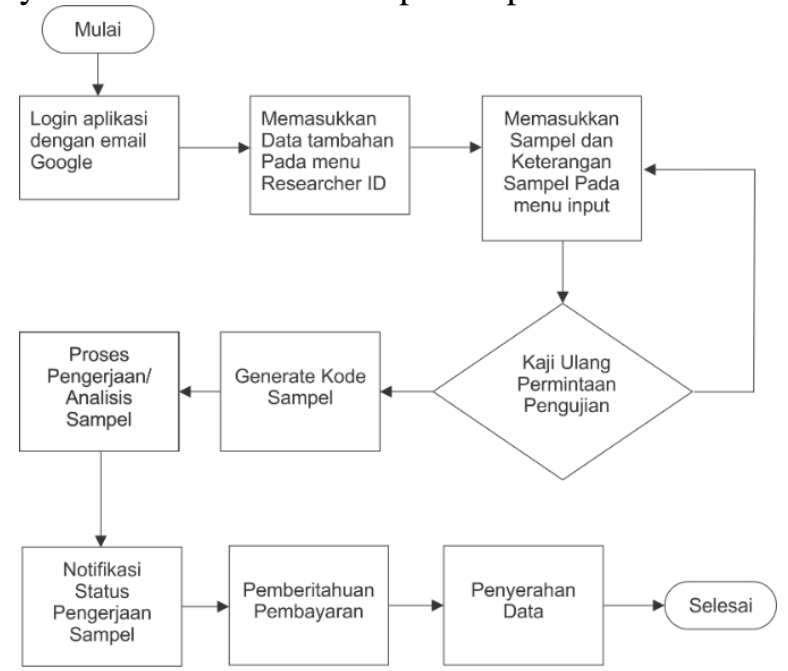

Gambar 3. Flow diagram Proses pengajuan analisis sampel 
Pada gambar 4 memperlihatkan use case diagram dari aktor yang terlibat pada sistem informasi yang dibuat. Aktor dari sistem ini terdiri dari pelanggan (user), administrator, manajer teknis, analis dan bendahara.

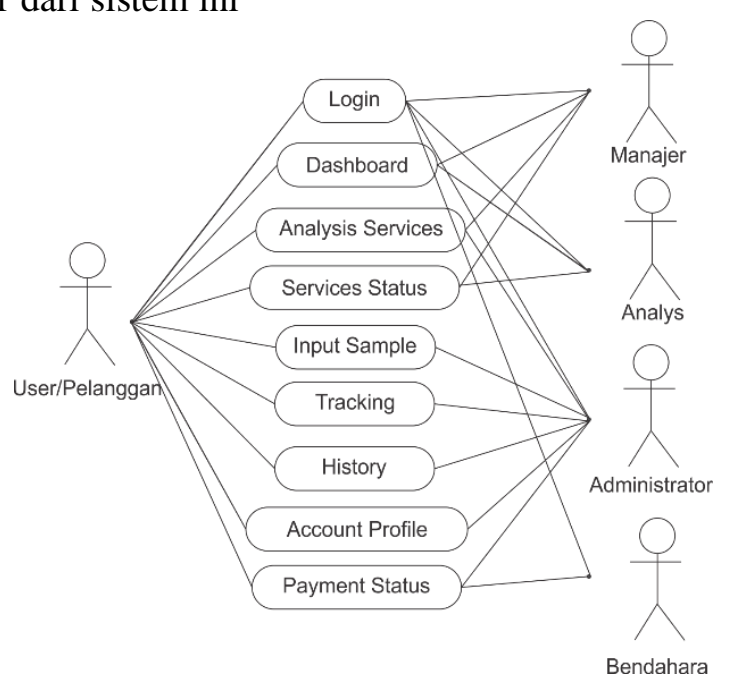

Gambar 4. Use Case Diagram sistem informasi analisis sampel

\section{HASIL DAN PEMBAHASAN}

Administrator layanan adalah petugas yang ditunjuk untuk menerima sampel kemudian mengkodekan sampel agar identitas pelanggan tidak dapat diketahui oleh pihak lain sehingga keamanan terjaga.

\section{Hasil CMS Website}

Administrator

Selain itu administrator bertanggung jawab dalam proses distribusi pengerjaan sampel. Tampilan menu utama (Dashboard) administrator layanan dapat dilihat pada gambar 5 .

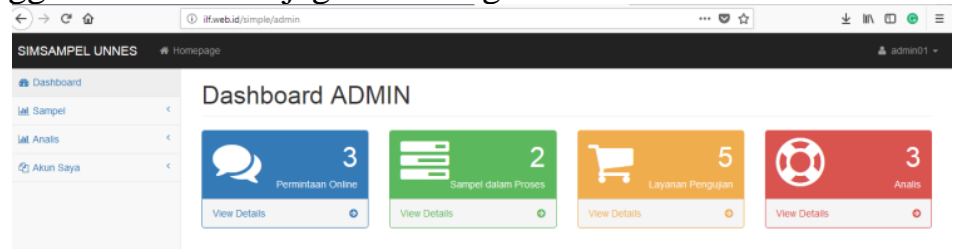

Gambar 5. Dashboard Administrator Layanan Pengujian Sampel

Dashboard pada masing-masing kelas user dibuat sesuai rancangan yaitu sebagai portal untuk dapat mengakses fitur atau menu lainnya. Menu yang terdapat pada akun administrator meliputi pengaturan Sampel,
Analis dan Akun saya. Pada menu sampel terdapat seluruh pengaturan terkait pengerjaan dan status sampel. Gambar 6 menunjukkan proses-proses yang terdapat pada menu sampel. 


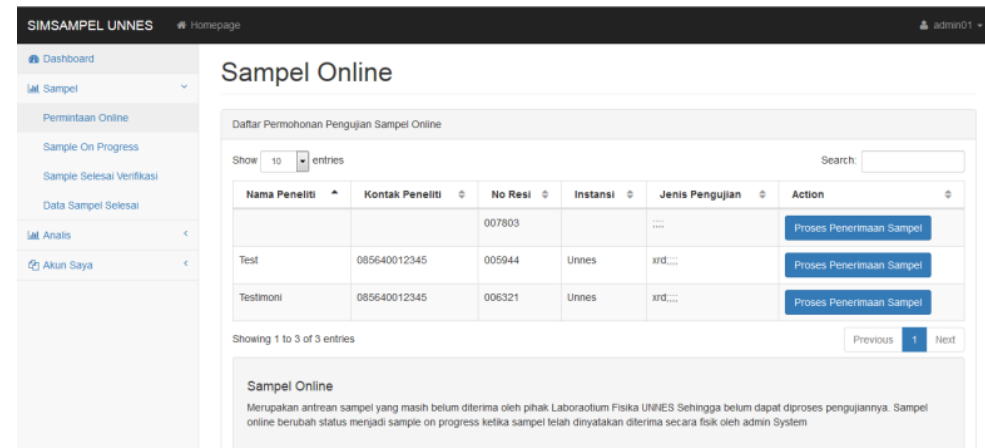

Gambar 6. Menu proses pada daftar permohonan pengujian

Menu permintaan sampel terdapat daftar permohonan pengujian sampel yang masuk ke laboratorium. Aksi yang dilakukan selanjutnya adalah memproses penerimaan sampel untuk mengubah status permintaan pada pelanggan menjadi diterima. Menu sample on progress menunjukkan daftar sampel yang sedang dikerjakan oleh analis.

\section{Analis}

Analis adalah orang yang ditunjuk karena kompetensinya untuk melakukan proses pengujian di laboratorium. Seorang analis harus memiliki kompetensi yang cukup dalam mengoperasikan dan menganalisa setiap pekerjaan yang ditugaskan. Pada laman analis menu yang tersedia adalah Penugasan Pengujian, Pengujian Sampel Selesai. Pada menu penugasan pengujian seorang analis dapat melihat daftar permintaan pengujian yang harus dikerjakan. Setelah selesai mengerjakan tugas, analis kemudian memberikan status pengujian sampel selesai untuk memberitahukan status kepada administrator.

\section{Manajer teknis}

Manajer teknis adalah orang yang ditunjuk untuk bertanggungjawab dalam
Pada tahapan ini status pada pelanggan akan berubah menjadi status sedang dikerjakan. Menu sample selesai verifikasi menunjukkan daftar data laporan hasil pengujian yang telah diverifikasi oleh manajer teknis. Menu data selesai berisi daftar sampel yang siap untuk diserahkan kepada pelanggan.

memeriksa laporan hasil pengujian yang dibuat oleh analis. Manajer teknis dalam hal ini dipegang langsung oleh kepala laboratorium. Menu yang terdapat pada akun manajer teknis adalah pengujian sampel. Menu tersebut berisi daftar pengujian serta laporan hasil pengujian. Manajer teknis dapat melihat sekaligus memverifikasi hasil pengujian. Jika hasil telah sesuai maka manajer teknis mengubah status pengujian menjadi terverifikasi.

\section{Aplikasi Android pada Client}

Aplikasi android fokus kepada fungsi yang ditawarkan sehingga untuk tampilan menggunakan design standard aplikasi. Login aplikasi dengan menggunakan akun google yang dimiliki oleh user. Laman login aplikasi dan pengisian identitas user dapat dilihat pada gambar 7 (a). 


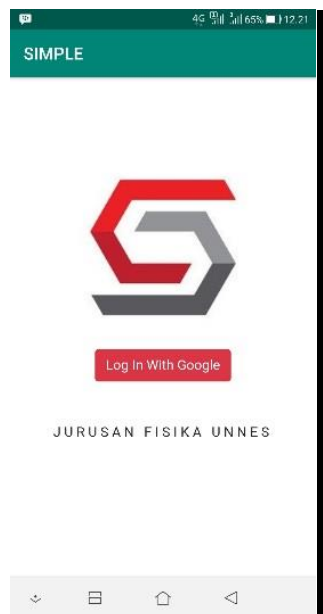

(a)

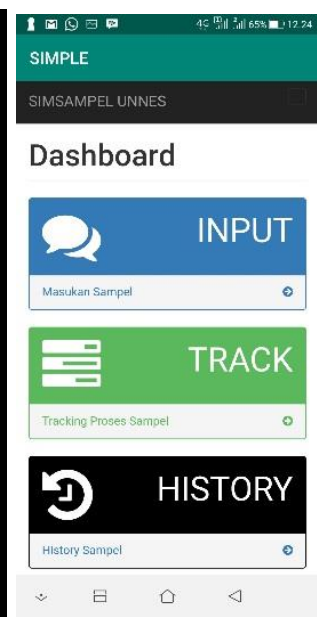

(b)

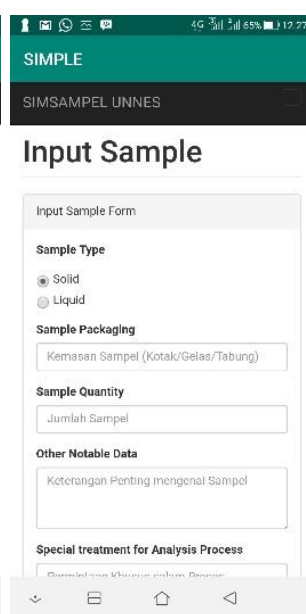

(c)

Gambar 7. (a) Laman login dengan akun goolgle (b) Dashboard Menu Utama Aplikasi (c) Laman memasukkan sampel

Pada aplikasi setelah user memiliki akun dan mengisi identitas kemudian akan masuk ke halaman dashboard yang memiliki lima menu utama (gambar 7b) yang terdiri dari: INPUT, TRACK, HISTORY, SERVICES, dan CONTACT. Menu INPUT berfungsi untuk memasukkan sampel. Menu TRACK berfungsi untuk melacak status sampel. Menu HISTORY berfungsi untuk melihat catatan analsis yang pernah dilakukan. Menu SERVICES memuat informasi jenis analisis yang dimiliki oleh laboratoorium fisika. Menu CONTACT berisi informasi kontak yang dapat dihubungi di Laboratorium Fisika Unnes.

\section{Pengujian Sistem}

Alpha Test dan Beta Test
Pada pengujian Alpha test sistem diuji secara fungsional pada masing-masing bagian menu dan sub menu. Dengan pengujian ini peneliti dapat memperbaiki sistem jika terdapat bagian-bagian yang terdapat kesalahan. Hasil pengujian Alpha Test dapat dilihat pada tabel 1.

Dari tabel 1 dapat dilihat bahwa hasil alpha test menunjukkan bahwa aplikasi telah mampu bekerja dengan baik. Pengujian selanjutnya adalah dengan meminta pendapat dari pengguna secara langsung. Beta test dilakukan dengan kuisioner pada pelanggan yang dibuat skala dari 1 sampai 4 . Dengan 1 = tidak baik, $2=$ kurang baik, $3=$ baik $4=$ sangat baik. Hasil pengujian beta test dapat dilihat pada grafik gambar 8 .

Tabel 1. Hasil Pengujian Alpha Test Pada Aplikasi

\begin{tabular}{llll}
\hline No & \multicolumn{1}{c}{ Kondisi } & \multicolumn{1}{c}{ Output } & Status \\
\hline $\mathbf{1}$ & $\begin{array}{l}\text { User dapat mengunduh aplikasi dan } \\
\text { menginstall pada gadget android }\end{array}$ & $\begin{array}{l}\text { Aplikasi terinstall dengan } \\
\text { baik pada } \text { gadget }\end{array}$ & valid \\
\hline $\mathbf{2}$ & $\begin{array}{l}\text { User dapat masuk dengan akun } \\
\text { google yang dimiliki dan mengisi } \\
\text { data identitas peneliti pada akun }\end{array}$ & $\begin{array}{l}\text { Akun dapat dipersonalisasi } \\
\text { oleh } \text { user }\end{array}$ & valid \\
$\mathbf{3}$ & $\begin{array}{l}\text { User dapat mengakses menu INPUT } \\
\text { untuk memasukkan sampel }\end{array}$ & $\begin{array}{l}\text { Permohonan analisis } \\
\text { sampel masuk dalam sistem }\end{array}$ & valid \\
\hline $\mathbf{4}$ & $\begin{array}{l}\text { User dapat melacak (tracking) } \\
\text { proses pengerjaan sampel }\end{array}$ & $\begin{array}{l}\text { Menampilkan status } \\
\text { pengerjaan sampel }\end{array}$ & valid \\
\hline
\end{tabular}




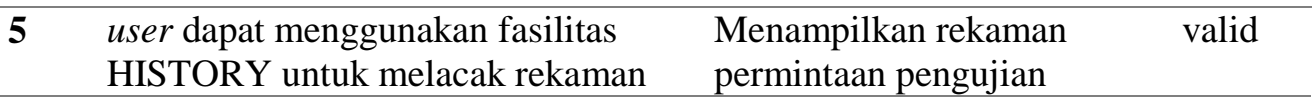

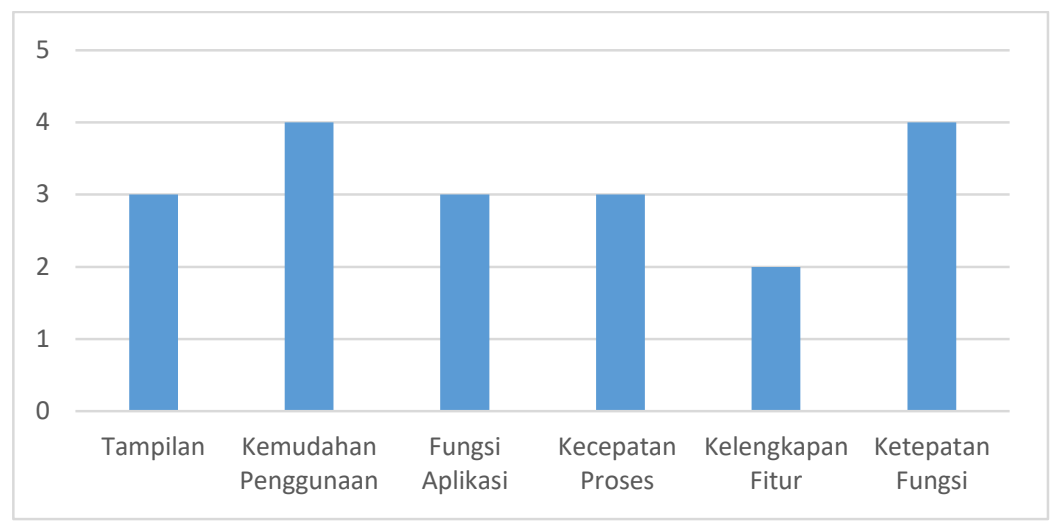

Gambar 8. Hasil pengujian beta test aplikasi

Dari hasil beta test dapat dilihat bahwa komponen utama yang perlu ditingkatkan adalah kelengkapan fitur aplikasi. Selain komponen tersebut aplikasi mendapat nilai positif dari responden.

\section{KESIMPULAN}

Simpulan dari penelitian ini adalah telah dilakukannya rancang bangun sebuah sistem informasi layanan analisis sampel pada Laboratorium Fisika yang dapat digunakan dengan baik. Selain itu aplikasi android yang telah dibuat juga mempermudah pengguna dalam mengajukan pengujian sampel di Laboratorium Fisika.

\section{DAFTAR PUSTAKA}

Irsan, Muhammad. (2015). Rancang bangun aplikasi mobile notifikasi berbasis android untuk mendukung kinerja di instansi pemerintahan. Jurnal sistem dan teknologi informasi. Volume 3 nomor 1 .

Jogiyanto, H. (2005). Analisis dan desain sistem informasi. Yogyakarta: Andi Offset

Juansyah, A. (2015). Pembangunan Aplikasi Child Tracker Berbasis AssistedGlobal Positioning System (A-GPS) Dengan Platform Android. Jurnal
Ilmiah Komputer Dan Informatika, l(1), 8

Musleh Al Hayubi, Zainal Arifin, F. H. (2016). Sistem Informasi Pengecekan Dan Monitoring Laboratorium Komputer Di STTNJ Berbasis Android Dan Web, 8, 37-42

Ramadhani, S., Anis, U., \& Masruro, S. T. (2013). Rancang Bangun Sistem Informasi Geografis Layanan Kesehatan Di Kecamatan Lamongan Dengan PHP MySQL. Jurnal Teknika, 5(2), 479-484.

Riyanto. (2011). Membuat Sendiri Aplikasi E-commerce dengan PHP dan MySQL Menggunakan Codeigniter dan JQuery. Yogyakarta: Andi Offset

Suharsana, I. K., Wirarama, I. G. P., Wirawan, W., Luh, N., \& Kartika, A. (2016). Implementasi Model View Controller Dengan Framework Codeigniter Pada E-Commerce Penjualan Kerajinan Bali. Jurnal Sistem Dan Informatika, 11, 19-28

Trisnato, P. Y., \& Lala, H. (2016). Perancangan Sistem Informasi Laboratorium Komputer Pada Program Studi D-III PMIK Poltekkes, 2152-2157. 